\title{
Alcaligenes aquatilis sp. nov., a novel bacterium from sediments of the Weser Estuary, Germany, and a salt marsh on Shem Creek in Charleston Harbor, USA
}

\author{
Stefanie Van Trappen, ${ }^{1,2}$ Tjhing-Lok Tan, ${ }^{3}$ Emly Samyn ${ }^{1}$ \\ and Peter Vandamme ${ }^{1}$ \\ 1,2 Laboratorium voor Microbiologie, Vakgroep Biochemie, Fysiologie en Microbiologie ${ }^{1}$ and \\ BCCM/LMG Bacteria Collection², Universiteit Gent, Gent, Belgium \\ ${ }^{3}$ Alfred-Wegener-Institut für Polar- und Meeresforschung, Bremerhaven, Germany
}

Four nitrite-dissimilating strains, isolated from Weser Estuary sediments, were investigated using a polyphasic taxonomic approach. Phylogenetic analysis based on 16S rRNA gene sequences indicated that these strains belong to the 'Betaproteobacteria' and are related to the genus Alcaligenes. The highest level of sequence similarity (100\%) was found with strain M3A (=ATCC 700596), a dimethyl sulfide-producing marine isolate that was included in this study.

DNA-DNA hybridizations between the five strains and related A/caligenes faecalis strains confirmed that the former belong to a single and novel species within the genus Alcaligenes. The isolates are Gram-negative, motile, rod-shaped cells with a DNA G $+\mathrm{C}$ content of about $56 \mathrm{~mol} \%$. The whole-cell fatty acid profiles of the isolates were very similar and included $\mathrm{C}_{16: 0}$, $\mathrm{C}_{17: 0}$ cyclo, $\mathrm{C}_{18: 1} \omega 7 \mathrm{c}$, summed feature 2 (comprising any combination of $\mathrm{C}_{12: 0}$ aldehyde, an unknown fatty acid of equivalent chain length $10 \cdot 928, \mathrm{C}_{16: 1}$ iso $\mathrm{I}$ and $\mathrm{C}_{14: 0} 3-\mathrm{OH}$ ) and summed feature $3\left(\mathrm{C}_{15: 0}\right.$ iso $2-\mathrm{OH}$ and/or $\left.\mathrm{C}_{16: 1} \omega 7 \mathrm{c}\right)$ as the major fatty acid components. On the basis of their phylogenetic, genomic and phenotypic properties, the five novel strains can be assigned to the genus Alcaligenes as a novel species, for which the name Alcaligenes aquatilis sp. nov. is proposed. The type strain is LMG $22996^{\top}$ (= CCUG $50924^{\top}$ ).

The genus Alcaligenes has undergone several changes since its creation in 1919, and is now limited to the species Alcaligenes faecalis (type species), which has been subdivided into $A$. faecalis subsp. faecalis and $A$. faecalis subsp. parafaecalis (Schroll et al., 2001), Alcaligenes latus (Palleroni \& Palleroni, 1978) and Alcaligenes defragrans (Foss et al., 1998). A. faecalis strains have been isolated from a wide variety of different habitats, e.g. soil, water and several clinical samples (Kersters \& De Ley, 1984; Schroll et al., 2001). A. defragrans strains have been isolated from soil and are capable of using alkenoic monoterpenes as sole carbon sources (Foss et al., 1998). A. latus is considered a species incertae sedis and recent data have shown

Published online ahead of print on 26 August 2005 as DOI 10.1099/ ijs.0.63849-0.

The GenBank/EMBL/DDBJ accession number for the 16S rRNA gene sequence of strain LMG $22996^{\top}$ is AJ937889.

A dendrogram derived from the linkage of correlation coefficients between the protein patterns of the strains studied and a digitized representation of normalized rep-PCR profiles are available as supplementary figures in IJSEM Online. that this organism belongs to the family Comamonadaceae (Coenye et al., 2003). Recently, another novel subspecies, 'A. faecalis subsp. phenolicus', isolated from a greywater bioprocessor, has been described (Rehfuss \& Urban, 2005).

A polyphasic taxonomic study was performed on five isolates from different aquatic habitats to elucidate their taxonomic position. The results of the genotypic and phenotypic analyses showed that they belong to a novel Alcaligenes species.

Four nitrite-dissimilating strains (LMG $22996^{\mathrm{T}}$, LMG 22997, LMG 22998 and LMG 22999) were isolated from Weser Estuary sediments in Germany (Rüger et al., 1983). Strain M3A ( = ATCC 700596) was isolated from salt-marsh sediment from the bank of Shem Creek in Charleston Harbor (South Carolina, USA) (de Souza \& Yoch, 1995). The reference strains A. faecalis subsp. faecalis LMG $1229^{\mathrm{T}}$, A. faecalis subsp. parafaecalis LMG $22680^{\mathrm{T}}$ and A. defragrans LMG $18538^{\mathrm{T}}$ were included in some experiments. All strains were routinely cultivated on trypticase soy agar at $28^{\circ} \mathrm{C}$ for $48 \mathrm{~h}$, except when mentioned otherwise. 
SDS-PAGE of whole-cell proteins of the five strains was performed and strains were grown on buffered nutrient agar for $48 \mathrm{~h}$ at $28^{\circ} \mathrm{C}$. Preparation of whole-cell proteins and SDS-PAGE were performed as described previously (Pot et al., 1994). Densitometric analysis, normalization and interpolation of the protein profiles, as well as numerical analysis using Pearson's product-moment correlation coefficient, were performed using the GELCOMPAR 4.2 software package (Applied Maths).

After numerical analysis and visual comparison of the profiles, one cluster could be delineated: strains LMG 22996 ${ }^{\mathrm{T}}$, LMG 22997, LMG 22998 and LMG 22999 showed almost identical profiles, whereas strains ATCC 700596, LMG $1229^{\mathrm{T}}$ (A. faecalis subsp. faecalis), LMG $18538^{\mathrm{T}}$ (A. defragrans) and LMG $22680^{\mathrm{T}}$ (A. faecalis subsp. parafaecalis) formed separate branches in the dendrogram (see Supplementary Fig. S1 available in IJSEM Online).

The five strains, together with the type strains of $A$. faecalis subsp. faecalis and A. faecalis subsp. parafaecalis, were arranged in similarity groups based upon the results of repPCR fingerprinting using the $\mathrm{GTG}_{5}$ and BOX primers (Versalovic et al., 1991; Rademaker \& de Bruijn, 1997; Rademaker et al., 2000). Numerical analysis was carried out using the BioNumerics 4.0 software package, as described by the same authors. Strains LMG 22996 ${ }^{\mathrm{T}}$, LMG 22997, LMG 22998 and LMG 22999 showed virtually identical profiles, whereas strain ATCC 700596 and the type strains of the two A. faecalis subspecies formed separate branches (see Supplementary Fig. S2 available in IJSEM Online).

Small-scale DNA extracts were prepared using the method of Pitcher et al. (1989) and a $1082 \mathrm{nt}$ fragment of the $16 \mathrm{~S}$ rRNA gene of strain LMG $22996^{\mathrm{T}}$ was amplified by a PCR using conserved primers (Coenye et al., 1999). PCR products were purified using a QIAquick PCR purification kit (Qiagen) according to the instructions of the manufacturer. Sequence analysis was performed as described previously (Van Trappen et al., 2004). Evolutionary distances were calculated using the algorithm of Jukes \& Cantor (1969) and a phylogenetic tree (Fig. 1) was constructed using the neighbour-joining method with the TREECON program (Van de Peer \& De Wachter, 1994).

The 16S rRNA gene sequence of strain LMG $22996^{\mathrm{T}}$ was compared with available $16 \mathrm{~S}$ rRNA gene sequences of other betaproteobacteria and was found to show $100 \%$ similarity to strain ATCC $700596,99 \cdot 6 \%$ similarity to A. faecalis subsp. parafaecalis, $98 \cdot 3 \%$ similarity to A. faecalis subsp. faecalis, $96 \cdot 4 \%$ similarity to 'A. faecalis subsp. phenolicus' and $94.0 \%$ similarity to $A$. defragrans. The phylogenetic tree in Fig. 1 illustrates the phylogenetic relationships within the genus Alcaligenes. Bootstrap analysis indicated that strains LMG $22996^{\mathrm{T}}$ and ATCC 700596 form a stable phylogenetic group (with a bootstrap value of $93 \%$ ).

The genomic relatedness between strains LMG $22996^{\mathrm{T}}$ and ATCC 700596 and the most closely related strains, A. faecalis subsp. faecalis LMG $1229^{\mathrm{T}}$, A. faecalis subsp. parafaecalis LMG $22680^{\mathrm{T}}$ and $A$. defragrans $\mathrm{LMG} 18538^{\mathrm{T}}$, was determined by DNA-DNA hybridization. DNA was prepared according to the method of Pitcher et al. (1989) and DNA-DNA hybridizations were carried out with photobiotin-labelled probes in microplate wells as described by Ezaki et al. (1989), using a HTS7000 Bio Assay Reader (Perkin Elmer) for the fluorescence measurements. The hybridization temperature was $42^{\circ} \mathrm{C}$ and reciprocal experiments were performed for every pair of strains. The level of hybridization between strains LMG $22996^{\mathrm{T}}$ and ATCC 700596 was $84 \%$, indicating that they belong to a single species (Wayne et al., 1987), whereas the DNA-DNA binding values with the other Alcaligenes strains were low (60\% with LMG $1229^{\mathrm{T}}$, $59 \%$ with LMG $22680^{\mathrm{T}}$ and $10 \%$ with LMG $18538^{\mathrm{T}}$ ). Differences between reciprocal experiments were less than $10 \%$. These results demonstrate that the five isolates are genotypically distinct from A. faecalis subsp. faecalis and A. faecalis subsp. parafaecalis, their nearest neighbours in phylogenetic terms, and constitute a novel species within the genus Alcaligenes.

The DNA G $+\mathrm{C}$ contents of the isolates were determined using an HPLC method as described by Van Trappen et al. (2003): the values for strains LMG $22996^{\mathrm{T}}$, LMG 22997 ,

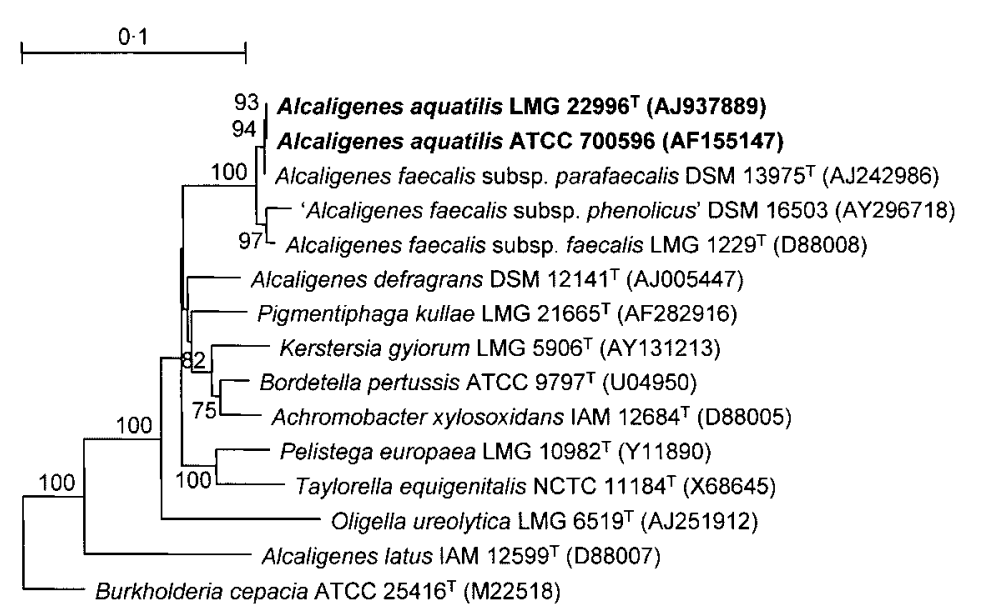

Fig. 1. Neighbour-joining phylogenetic tree, based on 16S rRNA gene sequences, showing the position of Alcaligenes aquatilis sp. nov. Bootstrap values are shown as percentages of 500 replicates, if greater than $70 \%$. Bar, 1 nucleotide substitution per 10 nt. GenBank accession numbers are shown in parentheses. Names that have not been validly published are in quotes. 
LMG 22998, LMG 22999 and ATCC 700596 are respectively $56,57,56,56$ and $55 \mathrm{~mol} \%$. These values are consistent with the $\mathrm{G}+\mathrm{C}$ contents of the genera Alcaligenes, Achromobacter and Pigmentiphaga, which range from 54 to $69 \mathrm{~mol} \%$ (Stolz et al., 2005).

The cellular fatty acid patterns of the strains were determined as described by Mergaert et al. (2001). The five strains showed very similar fatty acid profiles and the mean composition was $2 \cdot 3 \% \mathrm{C}_{10: 0}, 2 \cdot 6 \% \mathrm{C}_{12: 0} 2-\mathrm{OH}, 32 \cdot 7 \% \mathrm{C}_{16: 0}$, $13 \cdot 3 \% \mathrm{C}_{17: 0}$ cyclo, $1 \cdot 0 \% \mathrm{C}_{18: 0}, 9 \cdot 1 \% \mathrm{C}_{18: 1} \omega 7 c, 11 \cdot 3 \%$ summed feature 2 (which comprises any combination of $\mathrm{C}_{12: 0}$ aldehyde, an unknown fatty acid of equivalent chain length $10 \cdot 928, \mathrm{C}_{16: 1}$ iso $\mathrm{I}$ and $\left.\mathrm{C}_{14: 0} 3-\mathrm{OH}\right)$ and $24 \cdot 6 \%$ summed feature $3\left(\mathrm{C}_{15: 0}\right.$ iso $2-\mathrm{OH}$ and/or $\left.\mathrm{C}_{16: 1} \omega 7 c\right)$. In Table 1, the fatty acid compositions of several Alcaligenes species are compared: the profiles of the novel strains resemble those determined for the other members of the genus Alcaligenes. The dominant fatty acids are $\mathrm{C}_{16: 0}, \mathrm{C}_{17: 0}$ cyclo, $\mathrm{C}_{18: 1} \omega 7 c$, summed feature 2 and summed feature 3 ; the novel strains differ from the other Alcaligenes species in their relative amounts of $\mathrm{C}_{14: 0} 3-\mathrm{OH}, \mathrm{C}_{17: 0}$ cyclo and summed feature 3 .

The morphological, physiological and biochemical properties of the five novel strains were determined previously

Table 1. Fatty acid compositions of Alcaligenes species

Mean percentages of total fatty acids (with the corresponding standard deviations) are given for A. aquatilis (from five strains); data for $A$. faecalis subspecies represent single strains. Data are from Schroll et al. (2001), Rehfuss \& Urban (2005) and this study. Other fatty acids accounted for less than $1 \%$ each. Summed feature 2 comprises any combination of $\mathrm{C}_{12: 0}$ aldehyde, an unknown fatty acid of equivalent chain length 10.928, $C_{16: 1}$ iso $\mathrm{I}$ and $\mathrm{C}_{14: 0}$ 3-OH. Summed feature 3 comprises $\mathrm{C}_{15: 0}$ iso 2-OH and/or $\mathrm{C}_{16: 1} \omega 7 c$. Symbols: -, not detected; tr, trace amounts $(<1 \%$ of total).

\begin{tabular}{|lcccc|}
\hline \multirow{2}{*}{ Fatty acid } & A. aquatilis & \multicolumn{3}{c|}{ A. faecalis subspecies } \\
\cline { 3 - 5 } & & $\begin{array}{c}\text { subsp. } \\
\text { faecalis }\end{array}$ & $\begin{array}{c}\text { subsp. } \\
\text { parafaecalis }\end{array}$ & $\begin{array}{c}\text { 'subsp. } \\
\text { phenolicus' }\end{array}$ \\
\hline $\mathrm{C}_{10: 0}$ & $2 \cdot 3 \pm 0 \cdot 2$ & $1 \cdot 8$ & - & - \\
$\mathrm{C}_{12: 0}$ & $\operatorname{tr}$ & $1 \cdot 5$ & $\operatorname{tr}$ & $3 \cdot 2$ \\
$\mathrm{C}_{12: 0} 2-\mathrm{OH}$ & $2 \cdot 6 \pm 0 \cdot 4$ & $2 \cdot 6$ & $1 \cdot 9$ & $2 \cdot 2$ \\
$\mathrm{C}_{14: 0}$ & $\operatorname{tr}$ & $1 \cdot 1$ & $2 \cdot 2$ & $\operatorname{tr}$ \\
$\mathrm{C}_{14: 0} 3-\mathrm{OH}$ & - & - & $8 \cdot 6$ & $8 \cdot 1$ \\
$\mathrm{C}_{16: 0}$ & $32 \cdot 7 \pm 3 \cdot 9$ & $30 \cdot 6$ & $31 \cdot 4$ & $35 \cdot 8$ \\
$\mathrm{C}_{16: 1}$ & - & - & $30 \cdot 4$ & - \\
$\mathrm{C}_{17: 0}$ cyclo & $13 \cdot 3 \pm 5 \cdot 5$ & $27 \cdot 7$ & $16 \cdot 3$ & $9 \cdot 5$ \\
$\mathrm{C}_{18: 0}$ & $1 \cdot 0 \pm 0 \cdot 1$ & $1 \cdot 1$ & $\operatorname{tr}$ & $1 \cdot 1$ \\
$\mathrm{C}_{18: 1} \omega 7 c$ & $9 \cdot 1 \pm 2 \cdot 3$ & $11 \cdot 2$ & $7 \cdot 5$ & $1 \cdot 1$ \\
Summed & $11 \cdot 3 \pm 1 \cdot 2$ & $11 \cdot 0$ & - & $8 \cdot 4$ \\
feature 2 & & & & \\
Summed & $24 \cdot 6 \pm 2 \cdot 5$ & $10 \cdot 2$ & - & $29 \cdot 3$ \\
feature 3 & & & &
\end{tabular}

(Rüger et al., 1983; de Souza \& Yoch, 1995) and are listed below. Tests in the commercial API 20NE and API ID 32 GN systems (bioMérieux) were performed according to the instructions of the manufacturer. Anaerobic growth of the strains in the presence of nitrate and nitrite has been investigated and the reduction of nitrate and nitrite under anaerobic conditions has been tested according to the protocol of Smibert \& Krieg (1994). Alkali production from some organic salts and amides has been tested using the medium of Hugh and Leifson (see species description).

On the basis of this polyphasic taxonomic analysis, the five strains can be clearly differentiated from the other species within the genus Alcaligenes (Table 2) and should be assigned to a novel species, for which the name Alcaligenes aquatilis sp. nov. is proposed.

The status of $A$. defragrans merits further consideration. The large differences in DNA G $+\mathrm{C}$ content $(67 \mathrm{~mol} \%$ versus 56-59 mol\% for the other Alcaligenes species) and the absence of a significant phylogenetic bond (Fig. 1) indicate that it would be more appropriate to allocate this taxon to a distinct genus in the family Alcaligenaceae.

\section{Description of Alcaligenes aquatilis sp. nov.}

Alcaligenes aquatilis (a.qua'ti.lis. L. masc. adj. aquatilis living, growing or found in, or near, water, aquatic).

Cells are Gram-negative short rods $(0 \cdot 7-1 \cdot 1 \mu \mathrm{m} \times$ $1 \cdot 0-2 \cdot 5 \mu \mathrm{m})$ and are motile via peritrichous flagella. They form non-pigmented or yellow-pigmented (strains LMG

Table 2. Characteristics useful for differentiating $A$. aquatilis from related species

Taxa: 1, A. aquatilis; 2, A. faecalis subsp. parafaecalis; 3, A. faecalis subsp. faecalis; 4, 'A. faecalis subsp. phenolicus'. +, Positive; -, negative; $\mathrm{W}$, weak reaction; $\mathrm{ND}$, not determined.

\begin{tabular}{|lcccc|}
\hline Characteristic & $\mathbf{1}$ & $\mathbf{2}$ & $\mathbf{3}$ & $\mathbf{4}$ \\
\hline DNA G+C content (mol\%) & 56 & 56 & $56-59$ & $54 \cdot 8$ \\
Growth at $42{ }^{\circ} \mathrm{C}$ & - & - & + & + \\
Nitrite reduction & + & - & + & + \\
Assimilation of: & & & & \\
$\quad$ Glycogen & + & $\mathrm{W}$ & - & - \\
L-Histidine & + & - & + & + \\
L-Proline & - & + & + & + \\
L-Tryptophan & - & - & + & + \\
L-Serine & + & - & + & - \\
Malonate & - & + & + & + \\
Propionate & - & + & + & + \\
Suberate & + & $\mathrm{ND}$ & - & $\mathrm{ND}$ \\
Valerate & + & + & - & $\mathrm{ND}$ \\
$\alpha$-Hydroxybutyric acid & - & + & - & - \\
$\alpha$-Ketoglutaric acid & - & - & - & + \\
Degradation of gelatin & - & + & - & $\mathrm{ND}$ \\
\hline
\end{tabular}


22999 and ATCC 700596), circular, low-convex and smooth colonies with spreading, irregular edges and a diameter of $2 \cdot 0-5 \cdot 0 \mathrm{~mm}$ on trypticase soy agar plates after 2 days incubation at $28^{\circ} \mathrm{C}$. The growth temperature is in the range $4-35^{\circ} \mathrm{C}$, while the optimal growth temperature ranges from 18 to $24^{\circ} \mathrm{C}$. Tests for catalase and cytochrome oxidase are positive (except for strain ATCC 700596, which is catalasenegative). Nitrate and nitrite are not reduced under anaerobic conditions, but slight growth is observed under these conditions after 5 days incubation at $28^{\circ} \mathrm{C}$. Positive for the alkalinization of asparagine, citrate and glutamine. Positive for the utilization of sodium acetate, sodium citrate and malonate for most of the strains (with the exception of strain ATCC 700596, which is negative for utilization of sodium citrate and malonate). $\beta$-Galactosidase activity is not detected. Indole and hydrogen sulfide are not produced, and starch, gelatin, aesculin and urea are not degraded. Strains LMG 22996 ${ }^{\mathrm{T}}$, LMG 22997, LMG 22998 and LMG 22999 are able to reduce nitrite but not nitrate. No acids are produced from carbohydrates (except for strain ATCC 700596, which produces acid from maltose, mannitol, xylose and L-arabinose). No activity detected for arginine dihydrolase (variable for strain ATCC 700596), lysine decarboxylase or ornithine decarboxylase. Growth is not observed on glucose, L-arabinose, mannose, mannitol, $\mathrm{N}$-acetylglucosamine, maltose, gluconate, adipate, salicin, D-melibiose, L-fucose, D-sorbitol, propionate, 2-ketogluconate, 3-hydroxybutyrate, 4-hydroxybenzoate, L-proline, rhamnose, D-ribose, inositol, D-sucrose, itaconate, malonate, L-alanine or 5-ketogluconate. Growth is observed on caprate (except for strain ATCC 700596), malate, phenylacetate, valerate, citrate, histidine, suberate, acetate, DL-lactate, glycogen, 3-hydroxybenzoate and L-serine. Cells contain the fatty acids $\mathrm{C}_{16: 0}, \mathrm{C}_{17: 0}$ cyclo, $\mathrm{C}_{18: 1} \omega 7 \mathrm{c}$, summed feature 2 (comprising any combination of $\mathrm{C}_{12: 0}$ aldehyde, an unknown fatty acid of equivalent chain length 10.928, $\mathrm{C}_{16: 1}$ iso $\mathrm{I}$ and $\mathrm{C}_{14: 0} 3-\mathrm{OH}$ ) and summed feature $3\left(\mathrm{C}_{15: 0}\right.$ iso $2-\mathrm{OH}$ and/or $\left.\mathrm{C}_{16: 1} \omega 7 c\right)$ as the main constituents. The DNA $\mathrm{G}+\mathrm{C}$ content of the strains is $56 \mathrm{~mol} \%$.

The type strain is LMG $22996^{\mathrm{T}} \quad\left(=\mathrm{CCUG} 50924^{\mathrm{T}}\right)$. Reference strains are LMG 22997, LMG 22998 and LMG 22999, isolated from sediments of the Weser Estuary, Germany, as was the type strain, and M3A (=ATCC 700596), isolated from sediments of Shem Creek, Charleston Harbor, USA.

\section{Acknowledgements}

P.V. is indebted to the Fund for Scientific Research - Flanders (Belgium) for research grants.

\section{References}

Coenye, T., Falsen, E., Vancanneyt, M., Hoste, B., Govan, J. R., Kersters, K. \& Vandamme, P. (1999). Classification of Alcaligenes faecalis-like isolates from the environment and human clinical samples as Ralstonia gilardii sp. nov. Int J Syst Bacteriol 49, 405-413.
Coenye, T., Vancanneyt, M., Cnockaert, M. C., Falsen, E., Swings, J. \& Vandamme, P. (2003). Kerstersia gyiorum gen. nov., sp. nov., a novel Alcaligenes faecalis-like organism isolated from human clinical samples, and reclassification of Alcaligenes denitrificans Rüger and Tan 1983 as Achromobacter denitrificans comb. nov. Int J Syst Evol Microbiol 53, 1825-1831.

de Souza, M. P. \& Yoch, D. C. (1995). Purification and characterization of dimethylsulfoniopropionate lyase from an Alcaligenes-like dimethyl sulfide-producing marine isolate. Appl Environ Microbiol 61, 21-26.

Ezaki, T., Hashimoto, Y. \& Yabuuchi, E. (1989). Fluorometric deoxyribonucleic acid-deoxyribonucleic acid hybridization in microdilution wells as an alternative to membrane filter hybridization in which radioisotopes are used to determine genetic relatedness among bacterial strains. Int J Syst Bacteriol 39, 224-229.

Foss, S., Heyen, U. \& Harder, J. (1998). Alcaligenes defragrans sp. nov., description of four strains isolated on alkenoic monoterpenes $((+)$-menthene, $\alpha$-pinene, 2 -carene, and $\alpha$-phellandrene) and nitrate. Syst Appl Microbiol 21, 237-244.

Jukes, T. H. \& Cantor, C. R. (1969). Evolution of protein molecules. In Mammalian Protein Metabolism, pp. 21-132. Edited by H. N. Munro. New York: Academic Press.

Kersters, K. \& De Ley, J. (1984). Genus Alcaligenes Castellani and Chalmers 1919, 936 ${ }^{\mathrm{AL}}$. In Bergey's Manual of Systematic Bacteriology, vol. 1, pp. 361-373. Edited by N. R. Krieg \& J. G. Holt. Baltimore: Williams \& Wilkins.

Mergaert, J., Verhelst, A., Cnockaert, M. C., Tan, T.-L. \& Swings, J. (2001). Characterization of facultative oligotrophic bacteria from polar seas by analysis of their fatty acids and 16S rDNA sequences. Syst Appl Microbiol 24, 98-107.

Palleroni, N. J. \& Palleroni, A. V. (1978). Alcaligenes latus, a new species of hydrogen-utilizing bacteria. Int J Syst Bacteriol 28, 416-424.

Pitcher, D. G., Saunders, N. A. \& Owen, R. J. (1989). Rapid extraction of bacterial genomic DNA with guanidium thiocyanate. Lett Appl Microbiol 8, 151-156.

Pot, B., Vandamme, P. \& Kersters, K. (1994). Analysis of electrophoretic whole-organism protein fingerprints. In Chemical Methods in Prokaryotic Systematics, pp. 493-521. Edited by M. Goodfellow \& A. G. J. O'Donnell. Chichester: Wiley.

Rademaker, J. L. W. \& de Bruijn, F. J. (1997). Characterization and classification of microbes by rep-PCR genomic fingerprinting and computer assisted pattern analysis. In DNA Markers: Protocols, Applications and Overviews, pp. 151-171. Edited by G. CaetanoAnollés \& P. M. Gresshoff. New York: Wiley.

Rademaker, J. L. W., Hoste, B., Louws, F. J., Kersters, K., Swings, J., Vauterin, L., Vauterin, P. \& de Bruijn, F. J. (2000). Comparison of AFLP and rep-PCR genomic fingerprinting with DNA-DNA homology studies: Xanthomonas as a model system. Int J Syst Evol Microbiol 50, 665-677.

Rehfuss, M. \& Urban, J. (2005). Alcaligenes faecalis subsp. phenolicus subsp. nov. a phenol-degrading, denitrifying bacterium isolated from a graywater bioprocessor. Syst Appl Microbiol 28, 421-429.

Rüger, H.-J., Tan, T. L., Hentzschel, G. \& Naguib, M. (1983). New denitrifying Agrobacterium and Alcaligenes strains from Weser Estuary sediments: taxonomy and physiology. Veroff Inst Meeresforsch Bremerhav 19, 229-243.

Schroll, G., Busse, H.-J., Parrer, G., Rölleke, S., Lubitz, W. \& Denner, E. B. M. (2001). Alcaligenes faecalis subsp. parafaecalis subsp. nov., a bacterium accumulating poly-beta-hydroxybutyrate from acetonebutanol bioprocess residues. Syst Appl Microbiol 24, 37-43.

Smibert, R. M. \& Krieg, N. R. (1994). Phenotypic characterization. In Manual of Methods for General Microbiology, pp. 611-654. Edited by 
P. Gerhardt, R. G. E. Murray, W. A. Wood \& N. R. Krieg. Washington, DC: American Society for Microbiology.

Stolz, A., Bürger, S., Kuhm, A., Kämpfer, P. \& Büsse, H.-J. (2005). Pusillimonas noertemannii gen. nov., sp. nov., a new member of the family Alcaligenaceae that degrades substituted salicylates. Int J Syst Evol Microbiol 55, 1077-1081.

Van de Peer, Y. \& De Wachter, R. (1994). TREECON for Windows: a software package for the construction and drawing of evolutionary trees for the Microsoft Windows environment. Comput Appl Biosci 10, 569-570.

Van Trappen, S., Mergaert, J. \& Swings, J. (2003). Flavobacterium gelidilacus sp. nov., isolated from microbial mats in Antarctic lakes. Int J Syst Evol Microbiol 53, 1241-1245.
Van Trappen, S., Vandecandelaere, I., Mergaert, J. \& Swings, J. (2004). Flavobacterium degerlachei sp. nov., Flavobacterium frigoris sp. nov. and Flavobacterium micromati sp. nov., novel psychrophilic bacteria isolated from microbial mats in Antarctic lakes. Int J Syst Evol Microbiol 54, 85-92.

Versalovic, J., Koeuth, T. \& Lupski, J. R. (1991). Distribution of repetitive DNA sequences in eubacteria and application to fingerprinting in bacterial genomes. Nucleic Acids Res 19, 68236831.

Wayne, L. G., Brenner, D. J., Colwell, R. R. \& 9 other authors (1987). International Committee on Systematic Bacteriology. Report of the ad hoc committee on reconciliation of approaches to bacterial systematics. Int J Syst Bacteriol 37, 463-464. 